\title{
STOLEN WEALTH, PERPETRATORS AND PUNISHMENTS IN MOLDAVIA (17TH CENTURY - EARLY 18TH CENTURY)
}

\author{
CĂTĂLINA CHELCU
}

\begin{abstract}
For the historical period we refer to, no proper inventories have been made containing the unjustly appropriated goods. They are just mentioned as such or listed, if that was the case, according to the size of the damage. There are also documentary sources in which the object of the theft is less represented, the justice system focusing in those cases rather on the wrongdoers, than on the wrong actions. That is why, the blood money "paid for some reason", with no other specific details, is quite frequently cited. Rare or frequent, these documents are complaints addressed by the victim to the Prince and his officials, documents in which the perpetrators admitted their fault, or deeds issued by the judicial authority subsequent to the investigation of the criminal act. In discussing the theft of/from the wealth, i.e. from the whole amount of the available goods, we are interested in clarifying some aspects pertaining to a reality that the historian should reconstruct, with all the complexity of its evolution: the motivations of the theft and its circumstances, the types of theft, the social categories involved, the time and space of the misdemeanour, the perpetrators' punishment. Briefly, the study is about starting to write a history of the reprehensible acts liable to punishments for theft and robbery in 17th and early 18th century Moldavia.
\end{abstract}

STRESZCZENIE. Rabunek majątku, przestepcy i kary w Mołdawii (XVII w. - wczesny wiek XVIII).

Dla omawianego przez nas wieku nie tworzono żadnych właściwych wykazów bezprawnie przywłaszczonych dóbr. W niektórych przypadkach są one jedynie wspomniane lub wylistowane według rozmiaru szkody. Istnieją też źródła dokumentalne, które obiektom kradzieży poświęcają mniej uwagi, a system sprawiedliwości skupia się w tych przypadkach raczej na przestępcach i ich czynach. Dlatego też często przywołuje się tzw. okup krwi „płacony w określonym celu” i nie podaje się szczegółów spraw. Dokumenty te są zażaleniami adresowanymi przez ofiarę do księcia lub jego urzędników, są też pisane przez przestępców przyznających się do winy, lub też są to dokumenty wystawione przez władze sądownicze i poprzedzają one dochodzenie w sprawie kryminalnej. Rozważając kradzież części mienia tj. z całości dostępnych dóbr, naszym celem jest wyjaśnienie pewnych aspektów odnoszących się do rzeczywistości, którą historyk powinien zrekonstruować wraz z całą złożonością zmian tej rzeczywistości: motywami kradzieży i jej okolicznościami, typami kradzieży, związanymi z nią kategoriami społecznymi, czasem i przestrzenią występku, karą dla sprawcy. Rekapitulując, przedstawione w artykule badanie ogniskuje się na początkach tworzenia pisemnej historii dotyczącej nagannych aktów podlegających karze za kradzież i rozbój w XVII i w początkach XVIII wieku w Mołdawii.

Author: Cătălina Chelcu, Romanian Academy, A.D. Xenopol Institute of History, Iaşi, Romania, e-mail: catalina.chelcu@yahoo.com, ORCID iD: https://orcid.org/0000-0002-1941-9392

Keywords: stolen wealth, punishments, “okup krwi”, robber, criminal justice

Słowa kluczowe: rabunek majątku, kary, opłaty za „mokrą robotę”, rozboje, prawo kryminalne

Balcanica Posnaniensia. Acta et studia, XXVI, Poznań 2019, Wydawnictwo Instytutu Historii UAM, pp. 105129, ISBN 978-83-66355-32-3, ISSN 0239-4278. English text with summaries in English and Polish.

doi.org/10.14746/bp.2019.26.7 
For the historical period we refer to, no proper inventories have been made containing the unjustly appropriated goods. They are just mentioned as such or listed, if that was the case, according to the size of the damage. There are also documentary sources in which the object of the theft is less represented, the justice system focusing in those cases rather on the wrongdoers, than on the wrong actions. That is why, the blood money "paid for some reason", with no other specific details, is quite frequently cited. Rare or frequent, these documents are complaints addressed by the victim to the Prince and his officials, documents in which the perpetrators admitted their fault, or deeds issued by the judicial authority subsequent to the investigation of the criminal act. In discussing the theft of/from the wealth, i.e. from the whole amount of the available goods, we are interested in clarifying some aspects pertaining to a reality that the historian should reconstruct, with all the complexity of its evolution: the motivations of the theft and its circumstances, the types of theft, the social categories involved, the time and space of the misdemeanour, the perpetrators' punishment. Briefly, the study is about starting to write a history of the reprehensible acts liable to punishments for theft and robbery in 17th and early 18 th century Moldavia.

Based on large historical "investigations", the papers published in the western historiographic area, especially the French one, put forward new readings of different aspects of criminal reality, in different areas and periods. Among them, our attention was particularly drawn by: the exposure of the deepest resources of medieval and modern violence and the disclosure of its identity-related dimension, the approach of the theft issue, an everyday life-rooted crime ${ }^{1}$, and of robbery, or as Emmanuel Le Roy Ladurie put it, of the "crime against things", and how the imposition of specific methods of violence repression were justified ${ }^{3}$.

\footnotetext{
${ }^{1}$ Valérie Toureille, Vol et brigandage au Moyen Âge, Paris, Presses Universitaires de France, 2006, p. 1.

2 Emmanuel Le Roy Ladurie, Montaillou, sat occitan de la 1294 până la 1324, vol. II, translation in Romanian, foreword and notes by Maria Carpov, Bucharest, Editura Meridiane, 1992, p. 302 (French: Montaillou, village occitan de 1294 à 1324, Paris, Gallimard, 1975).

${ }^{3}$ Here are, in a brief enumeration, some of these contributions: Bronislaw Geremek, Les marginaux parisiens aux XIV et XVe siècles, Paris, Flammarion, 1976; Jacques Chiffoleau, Les justices du pape. Délinquance et criminalité à Avignon au XIV siècle d'après les registres de la cour temporelle, Paris, Publications de la Sorbonne, 1984; Claude Gauvard, "De grace especial». Crime, État et Société en France à la fin du Moyen Âge, 2 vol., Paris, Publications de la Sorbonne, 1991; idem, Violence et ordre public au Moyen Age, Paris, Picard, 2005; Patrick J. Geary, Le vol des reliques au Moyen Âge. Furta sacra, traduit de l'anglais par Pierre-Emmanuel Dauzat, Paris, Aubier, 1993; Banditisme et violence sociale dans les sociétés de l'Europe méditerranéenne, dans Actes du colloque de Bastia (27-29 mai 1993), textes réunis par G. Ravis-Giordani et A. Rovere, Ajaccio, La marge éditions, 1997; M. P. Di Bella (dir.), Vols et sanctions en Méditerrannée, Amsterdam, Éditions des Archives contemporaines, 1998; Marie-Sylvie Dupont-Bouchat, Le crime pardonné: la justice réparatrice sous l'Ancien Régime (XVIe-XVIII siècle), dans "Criminologie", 32, no. 1, 1999, p. 31-56; B. Garnot (dir.), De la déviance à la délinquance, XV$X X^{e}$ siècles, Dijon, Éditions universitaires de Dijon, 1999; David Nirenberg, Violence et minorités au Moyen Âge, Paris, PUF, 2001; Valérie Toureille, Vol et brigandage au Moyen Âge, Paris, PUF, 2006; Bruno Lemesle, Conflits et justice au Moyen Âge, Paris, PUF, 2008; Loïc Cadiet, Frédéric Chauvaud,
} 
Historians have not yet given a monographic perspective upon theft and robbery in the medieval and premodern period Moldavia. What we have is a look upon violence in general, and upon the levers of its domination power south and east the Carpathians ${ }^{4}$. Highlighting some aspects regarding the significance of the phenomenon of social discipline, the issue of the 'haiduci' [outlaws, brigands] from Transylvania, Bihor and Moldavia, situations and perceptions of the soldier at the beginning of the modern period in Transylvania and Bihor areas ${ }^{5}$ represent important steps towards a history of the acts to be labelled as theft, with or without violence, which, together with other actions, in a given historical context, caused the inhabitants a feeling of insecurity". The 'righteous' felt menaced by the "wrongdoers in the village, thieves or robbers". The latter's acts and the outcomes of their acts will make the object of our preliminary approach in the following lines.

\section{COMMON THIEF OR THEFT}

The thieves, who were peasants, freemen or serfs ${ }^{7}$, Gypsies or servants ${ }^{8}$, foreigners ${ }^{9}$, Turks or Tartars who were committing thefts especially in the border areas ${ }^{10}$,

Claude Gauvard, Pauline Schmitt Pantel et Myriam Tsikounas (dir.), Figures de femmes criminelles de l'Antiquité à nos jours, Paris, Publications de la Sorbonne, 2010; Benoît Garnot, La violence dans la France moderne: une violence apprivoisée?, dans Mélanges offerts au professeur Maurice Gresset. Des institutions et des hommes, Besançon, Presses universitaires de Franche-Comté, 2007, p. 93-10; idem, Au temps de bons juges d'Ancien Régime, dans "L'Histoire", 2010, p. 78-83; Sarah Auspert, Isabelle Parmentier, Xavier Rousseaux, Buveurs, voleuses, insensés et prisonniers à Namur au XVIIIe siècle. Déviance, justice et régulation sociale au temps des Lumières, Namur, Presses Universitaires de Namur, 2012.

${ }^{4}$ Dan Horia Mazilu, Lege şi fărădelege în lumea românească veche, Iași, Polirom, 2006.

${ }^{5} \mathrm{We}$ are referring to the following studies, collected in Caiete de antropologie istorică, yr IX, no. 1 (16), January-June 2010, an issue dedicated to: Haiducie, brigandaj şi disciplinare social ['Haiducie', Brigandage and Social Discipline]: Toader Nicoară, Disciplinarea socială şi modernitatea - lecturi posibile [Social Discipline and Modernity - Possible Readings]; Ioan Ciorba, Cristian Apati, Lotria in Arad şi Bihor în a dona jumătate a secolului al XVIII-lea şi măsuri de combatere a acesteia reflectate în circularele bisericessti [Brigandage in Arad and Bihor in the Second Half of the $18^{\text {th }}$ Century and Measures to Fight it as Reflected in Church Circulars]; Arcadie M. Bodale, Contribuţii la istoria haiduciei in Moldova [Contributions to the History of Brigandage in Moldavia]; Barbu Ştefănescu, Soldaţi in campanie, soldaţi încartiruiţi, soldaţi vagabonzi la începuturile epocii modern [Soldiers in Campaign, Billeted Soldiers, Vagabond Soldiers in Early Modern Period]; Marin Sâmbrian-Toma, Estetizarea tâlhăriei: haiducul, criminal sau erou? [Estheticizing Robbery: the 'Haiduc' - Criminal or Hero?]

${ }^{6}$ The state of general insecurity, caused by calamities, wars, etc., is highlighted in the two volumes signed by Toader Nicoară, i.e. Sentimentul de insecuritate în societatea românească la începuturile timpurilor moderne (1600-1830) [The Feeling of Insecurity in Romanian Society in Early Modern Times (1600-1830)], vol. I, Cluj-Napoca, Editura Accent, 2002, and vol. II, 2005.

${ }^{7}$ DRH, A. Moldova, XXV (1639-1640, ed. Nistor Ciocan, Dumitru Agache, Georgeta Ignat and Marius Chelcu, Bucharest, Editura Academiei Române, 2003, p. 198-199, no. 189; p. 487, no. 500, a document from 15 December 1640. 
women, who were either the proven perpetrators ${ }^{11}$ or the robbers' hosts ${ }^{12}$, tried, by redeeming the guilt - the blood money to save them from "hanging" 13 , from "the gallows" 14 or from "the rope" 15 -, to stay alive, in different ways: by renouncing the land they owned (in most of the cases), by losing freedom and becoming a serf(bonded peasant) ${ }^{16}$ for the one who paid the criminal fine to the court and the compensations to the injured party, or by changing the lord of the Gypsy slave who had been proven to have stolen and whose "blood" was bought 17 .

In a document including the amounts of money spent by the master of some Gypsies - Strătulat and his brother, Savin - in order to pay the injured parties, as well as to pay off the fine to the princely court in order to save them from being punished,

${ }^{8}$ Aniţa Vântoaie left with the money stolen from her master's house (National Archives of Iași, Monastery of Doljeşti, XXbis/24; document from 7 January 1714). Two robbers, both named Ştefan, together with Nedelco, former valet of Grigorie, former captain of Covurlui, stole a horse and 5 mares from priest Melahie from Bursuci, country of Tutova. The Prince sent the perpetrators to jail, while Gligorie the captain was to look for Nedelco and "to get him in the stocks and bring him to the Prince's man" (Documente privitoare la istoria oraşului Iassi [Documents about the history of the city of Iasi], vol. V, Acte interne (1741-1755) [Internal Documents (1741-1755)], ed. Ioan Caproşu, Iaşi, Editura "Dosoftei", 2001, p. 103, no. 182; a document dated 5 February 1742).

${ }^{9}$ Ion Rus, stove maker, stole an ox from Toader, a chamberlain of Cobolta (Condica lui Constantin Mavrocordat [Constantin Mavrocordat's Code], vol. II, ed. Corneliu Istrati, Iaşi, Editura Universităţii “Al. I. Cuza", Iaşi, 2008, p. 359-360, no. 1098 (document dated: 17 November <1741>).

${ }^{10}$ Condica lui Constantin Mavrocordat (Constantin Mavrocordat's Code), vol. III, p. 141-142, no. 1959 ; p. 142 , no. 1960.

${ }^{11}$ National Archives of Iași, Monastery of Doljeşti, XXbis/24 (document from 7 January 1714).

${ }^{12}$ Aniţa, from the village of Movilău, had hosted Russian soldiers who had stolen from the goods of some merchant (Condica lui Constantin Mavrocordat, II, p. 82, no. 231).

${ }^{13}$ Document from 8 August $<1610-1611>\left(D I R, 17^{\text {th }}\right.$ Century, A. Moldova, vol. II (1606-1610), Bucharest, 1953, p. 314-315, no. 419).

${ }^{14}$ National Archives of Iaşi, Ms. no. 818 (Condica Moşiei Miclăuşeni - Code of the Estate of Miclăuşeni), f. 63 (document dated: $<1616-1618>$, according to Catalogul documentelor moldoveneşti din Arhiva Istorică Centrală a Statului (Catalogue of Moldavian Documents in the State Central Historical Archives), Supliment (Supplement), I, Bucharest, 1975, p. 128, no. 324).

${ }^{15}$ DRH, A. Moldova, XXI (1632-1633), eds. C. Cihodaru, I. Caproşu and L. Şimanschi, Bucharest, 1971, p. 279-280, no. 221 (document from 22 September 1632).

${ }^{16}$ National Archives of Iași, Ms. no. 628, Asachi Register, f. 316v. Document dated: $<1668-1670>$, according to Catalogul documentelor moldovenești din Arhiva Istorică Centrală a Statului, III, Bucharest, 1968, p. 367 , no. 1720 ; f. 317 r.

${ }^{17}$ DRH, A. Moldova, XVII, II, p. 229-231, no. 306. ANIC, New Acquisitions, MMCMV/6, no. 75. DRH, A. Moldova, XXI, p. 99-100, no. 90; p. 519-520, no. 414, document from 23 November 1633, Iaşi. DRH, A. Moldova, XXVII (1643-1644), eds. Petronel Zahariuc, Cătălina Chelcu, Marius Chelcu, Silviu Văcaru, Nistor Ciocan and Dumitru Ciurea, Bucharest, Editura Academiei Române, 2005, p. 80, no. 70; document from 7 April 1643. D. Constantinescu, Documente moldoveneşti din secolele XV-XVII $\left(15^{\text {th }}\right.$ $17^{\text {th }}$ Century Moldavian Documents), in AIIAI, VII, 1970, p. 348, no. 17. Gh. Ghibănescu, Surete şi izvoade (Documents and Registers), XXIV, Iaşi, 1939, p. 133-134, no. 119. ANIC, New Acquisitions, MMCMV/6, no. 73. National Archives of Iași, Monastery of Brazi, XXXIII/7. National Archives of Iași, Monastery of Precista - Răducanu, XVII/6 (document from 12 November 1703); idem, Ms. no. 572 (Register of the Monastery of Răchitoasa), f. 158 (document from 25 January 1704). 
while they were seized in a jail at Hotin, we can also read about the goods the two had stolen in 1716:

+ 10 lei a mare I gave to Iordăchioaia from Pășcan(i) for Strătulat the Gypsy with his brother, Savin, when they brought them from Ț(a)ra Românească [Wallachia], for having stolen;

+ 14 lei I gave to Hărțăscul Vasil(e) for a big bucket of beer, and the same for Strătulat with his brother for having stolen it;

+5 lei I gave for 5 bushels of wheat that was taken by Strătulat, together with money and wine, and then he ran away, and that I paid;

+30 lei a horse stolen by Strătulat and Savin when they ran away and a bucket and an axe.

+1 leu p(o)l I gave to a priest from Păşcan(i), the same

+4 lei I spent wishing to get them out from Hotin ${ }^{18}$.

But there are also cases when some Gypsies, smiths - who were first accused of fraud because of selling a piece of silver that proved to be mixed with lead when the buyer tried to re-sell it to some Armenian merchants, then accused of the theft, presupposed and proven, of nine lei from an alewife, who kept the money "in a chest, while her supposition was that those Gypsies unlocked it with her key, as they saw where she had put the key and one of them duped her, going with her to the cellar, while the other remained in the house, and thus they took the money - manage to escape punishment by guarantors or, after being beaten, by paying off the damage ${ }^{19}$.

Some of the thieves were known by the community because of the menace they represented. That was the case of a recidivist, Tiron Cucoranu, mentioned above, who had committed three murders and was redeemed by his brother, Cristea ${ }^{20}$; the irony of fate was that he died murdered himself ${ }^{21}$.

It seems that the important thing in succeeding was the moment of action. The darkness encouraged the surprise attacks, slowed the victims down in defending themselves, and impeded the identification of the perpetrators. That is why, the thieves preferred to commit their reprehensible deeds during the night. For instance, in February 1634, the owners of a plot of land were complaining that "their documents had burned... when the robbers had come by night and lit their house with them inside, and much wealth and many goods burnt in the house, they just managed to save themselves ${ }^{22}$. Sunset is also a good moment: from the Armenian Andronic and from

18 National Archives of Iaşi, Monastery of Doljeşti, XX/2 (document from 1716 (7224), f.l.z.).

19 Documente privitoare la istoria oraşului Iaşi [Documents Regarding the History of the City of Iasi], V, p. 72-73, no. 131 (document dated: 8 December <1741>).

${ }^{20}$ Document from 22 November 1622 (DIR, $17^{\text {th }}$ Century, A. Moldova, vol. IV (1616-1620), Bucharest, 1956, p. 299-300, no. 368); see also ibidem, V, p. 153-154, no. 214 (document from 1 August 1622).

${ }^{21}$ DRH, A. Moldova, XXIII (1635-1636), edited by Leon Şimanschi, Nistor Ciocan, Georgeta Ignat and Dumitru Agache, Bucharest, Editura Academiei Române, 1996, p. 8, no. 6.

${ }^{22}$ DRH, A. Moldova, XXII (1634), eds. C. Cihodaru, I. Caproşu and L. Şimanschi, Bucharest, 1974, p. 50, no. 46. Travellers were warned by locals to travel during the day only, as the robbers were attacking at night. One of these travellers was the Italian monk Niccolò Barsi, who, on his way to Anatolia and passing through Dobrogea, was afraid not to be killed by the robbers in the area - the host where he had spent 
Constantin from Suceava were stolen 1,000 lei with which they had to buy some sheep "on Tuesday, October 27, at eventide" 23 .

Among the motivations invoked by the perpetrators, there was one which made theft the most frequent crime, and that was hunger. Consequently, stealing food was an ordinary action at that time: "due to lack", that is how were justifying in 1662 Tudor and his son in law, Pavel, the fact they had stolen cheese, flour, beehives and whatever they found to eat from a cache, in Dolhești, belonging to Apostol; they paid afterwards to the injured party 30 plots of land, estimated at $60 \mathrm{le}^{24}$. The lacks were also invoked in 1713 in the case of some stolen money: "cause he was a poor man", that is how the witnesses justified the theft committed by Ursul mutul [the dumb] ${ }^{25}$. Yet, even if the food deficit brought people on the verge of despair, some of them found different means to overcome their natural physiological sensations: selling an abandoned vineyard because "of the famine and all the lacks, hunger was difficult" 26 or a plot of land "because of the misery we got to live in these awful days" 27.

Besides the "current" thefts of goods, i.e. cattle $\left(\mathrm{oxen}^{28}, \operatorname{cows}^{29}\right)$, horses ${ }^{30}, \mathrm{pigs}^{31}$, cereals, in general, that is the "stolen bread" from pits $^{32}$, beehives ${ }^{33}$, money - secretly

the night had warned him, recommending to take a guide (Călători străini despre Țările Române [Foreign Travellers about the Romanian Principalities], V, ed. Maria Holban, M. M. Alexandrescu-Dersca Bulgaru and Paul Cernovodeanu, Bucharest, 1973, p. 85).

${ }^{23}$ Condica lui Constantin Mavrocordat [Constantin Mavrocordat's Code], III, p. 128-129, no. 1913; ibidem, p. 141-142, no. 1959.

${ }^{24}$ National Archives of Iaşi, Bishopric of Huşi, XXIV/5.

${ }^{25}$ Idem, Monastery of Doljeşti, XXbis/84 (no. 29) (document from 13 August 1713).

${ }^{26}$ Idem, Monastery of Brazi, XVII/12 (document from 21 June 1686).

${ }^{27}$ ANIC, collection S. Zotta, file no. 144, f. 53.

${ }^{28}$ DIR, A. Moldova, XVII, II, p. 132, no. 162 (document dated: 23 November $<1607-1609>$ ); DRH, A. Moldova, XXIV (1637-1638), eds. C. Cihodaru and I. Caproşu, Bucharest, Editura Academiei Române, 1998, p. 81-82, no. 83 (document from 4 May 1637, Siret); National Archives of Iași, Bishopric of Huşi, LXXII/1 (document dated: <about 1657-1659>, according to Supliment, I, p. 244, no. 745); C. Stoide, Despre schitul Fătăciune şi despre satele Cernueşti şi Praja [About the Skete of Fătăciune and about the Villages of Cernueşti and Praja], in RIR, XIV, 1944, 209 (document from 17 July 1661); National Archives of Iaşi, Monastery of Neamţ, XXVII/10 (document from 20 July 1688, Iaşi); idem, Monastery of Slatina, VI/7 (no. 3) (document from 25 July 1701); idem, Manuscript no. 656 (Code of Soveja Monastery), f. 52 v. (document dated: <about 1713>, according to Catalogul documentelor moldoveneşti din Arhivele Istorice Centrale [Catalogue of the Moldavian Documents in the Central Historical Archives], V, Bucharest, 1974, p. 325 , no. 1197).

${ }^{29}$ DIR, $17^{\text {th }}$ Century, A. Moldova, vol. III (1611-1615), Bucharest, 1954, p. 8, no. 10 (document from 25 February 1611); p. 10, no. 11.

${ }^{30}$ Din tezaurul arhivistic vashian. Catalog de documente, 1393-1877 [Archives Treasury of Vaslui. Document Catalogue], p. 32, no. 43 (document from 4 August 1603); DIR, A. Moldova, XVII, II, p. 79-80, no. 91 (document from 10 January 1607); ibidem, p. 311-312, no. 414 (document from 22 July 1610, Iaşi); ibidem, p. 314-315, no. 419 (document dated: 8 August <1610/1611>, Iaşi); ibidem, p. 301-302, no. 401 (document from 12 June 1610, Iaşi); "Dr. Constantin I. Istrati” Collection (1429-1945). Inventar arhivistic [Archive Inventory], eds. Nicolae Chipurici and Tudor Rățoi, Bucharest, 1988, p. 61, no. 74 (document dated: 6 February <1623>, Siviţa); DRH, A. Moldova, XXI, p. 279-280, no. 221 (document from 22 September 1632); ibidem, p. 364, no. 284 (document from 2 February 1633); idem, XXIII, p. 51, no. 
and unjustly appropriated from the master's house ${ }^{34}$, or the money resulted from the sale of mead and wine ${ }^{35}$ or from the collection of taxes ${ }^{36}$-, highway robberies or robberies in hidden places, where the owners of goods were trying to place out of view the savings of a lifetime, show sometimes small fortunes, for the recovery of which the injured party had to go through trials for years or just to hope for the thieves to be found.

For instance, the wife of Luca, the chief of catchpoles, daughter of Costantin of Dolhești, being on her deathbed, testifies in June 1640, in the presence of witnesses, for the knowledge of her son, Apostol, showing all the things that had been stolen

52 (document from 5 March 1635, Iaşi); ibidem, p. 185-186, no. 147 (document from 29 June 1635, Iaşi); ibidem, p. 185-186, no. 147 (document from 29 June 1635, Iaşi); idem, XXVIII (1645-1646), eds. Petronel Zahariuc, Marius Chelcu, Silviu Văcaru and Cătălina Chelcu, Bucharest, Editura Academiei Române, 2006, p. 36-37, no. 44 (document dated: <1645, March 31 - 1645, September 10>); National Archives of Iaşi, Moldavia's Metropolitan Church, CXLI/2, (document from 1664, no month and day provided); ANIC, S. Zotta collection, file no. 25, f. 85-86 (document from 30 March 1676); Documente privitoare la istoria oraşului Iaşi [Documents regarding the History of the City of Iasi], V, p. 124, no. 221 (document from 31 March 1742); National Archives of Iași, Monastery of "Sf. Ioan Gură de Aur' [St. John Chrysostom], VIII/1 (document from 15 August 1711); idem, Manuscr. no. 628 (Asachi Code), f. 500 (document from 22 December 1711); Documente privitoare la istoria oraşului Iaşi, V, p. 103, no. 182 (document from 5 February 1742); ibidem, p. 124, no. 221 (document from 31 March 1742).

${ }^{31}$ National Archives of Iași, Manuscr. no. 572 (Code of Răchitoasa Monastery), f. 73 v. (document from 6 September 1687).

32 National Archives of Iași, Bishopric of Huşi, XXIV/181 (no. 13) (document dated: <16761680>, according to Catalogul documentelor moldoveneşti din Arhivele Istorice Centrale ale Statului [Moldavian Documents Catalogue in the Central State Historical Archives], IV, Bucharest, 1970, p. 49, no. 115); ANIC, New Acquisitions, MMCMV/18 (no. 4), document from 25 April 1685; National Archives of Iași, Ştoboreni Monastery, VIII/2 (no. 7), document from 1 March 1687; idem, Bishopric of Huşi, XII/32 (document from 1701, no month and day provided); idem, Bishopric of Huşi, XII/129 (document dated: 28 November $<1705>$, according to Catalogul documentelor moldoveneşt $i$ [Catalogue of Moldavian Documents], V, p. 129, no. 498).

${ }^{33}$ DRH, A. Moldova, XXIII, p. 85-86, no. 70 (document from 25 March 1635); idem, XXIV, p. 141143, no. 50 (document from 11 July 1637, Iaşi); idem, XXVI (1641-1642), ed. I. Caproşu, Bucharest, Editura Academiei Române, 2003, p. 237-238, no. 286 (document from 1 November 1641, Iaşi); ANIC, New Acquisitions, A.N., XCI/68 (document from 2 July 1684); see also the National Archives of Iași, Ms. no. 575 (Code of Răchitoasa Monastery), f. 104v. (document from1 April 1685); idem, Bishopric of Huşi, XXV/15 (document from 24 April 1686); ANIC, New Acquisitions, CCLXXXI/66 (document dated: $<$ d. 1686 (7194)> Apr. 29, according to Catalogul documentelor moldoveneşti [Moldavian Documents Catalogue], IV, p. 228, no. 1005); National Archives of Iaşi, Manuscript no. 573 (Code of Răchitoasa Monastery), f. 70 (document from 20 June 1686); idem, Răchitoasa Monastery, X/25 (document from 7 October 1690).

${ }^{34}$ National Archives of Iași, Doljeşti Monastery, XXbis/24 (document from 7 January 1714).

${ }^{35}$ Idem, XXXbis/84 (no. 31), document from 19 April 1714; Documente privitoare la istoria oraşului Iassi [Documents regarding the History of the City of Iasi], vol. II, Acte interne (1661-1690) [Internal Documents], ed. Ioan Caproşu, Iaşi, Editura "Dosoftei", 2000, p. 431, no. 475 (document from 12 June 1677).

${ }^{36}$ Condica lui Constantin Mavrocordat [Constantin Mavrocordat's Code], II, p. 106, no. 300 (document from 14 October 1741). 
from a chest hidden in a gully where she had had the apiary, at some distance from the house: "what we had, everything, there, for bad times", i.e.: 2 lengths of fabric, "a thin one and one for domestic needs", measuring 100 coți [ancient local unit of about $0.600 \mathrm{~m}$ ], a ball of beeswax weighing $80 \mathrm{okas}$, a deed of property for the estate of Dolhești that had belonged to her husband, and a pair of "good" pistols; she hoped for the thief to be found ${ }^{37}$.

A document from 1 July 1656, issued in Iași, shows that ritual objects and money were stolen from the church: a shoemaker from Iași, Iacob, stole from the Three Hierarchs monastery "a little case (that is chest) with many things inside, namely: a gem and four sets of holy relics, and money amounting to twenty golden coins, and eighty lei, and silverware". The document shows that, wishing to redeem his guilt, the thief had to indemnify the monastery for the loss, offering it a house with land in Târgul Vechi from Iași, which, at the time the document was written, was sold by the starets Galaction to Iani the chamberlain for $60 \mathrm{lei}^{38}$; for his guilt, Iacob the shoemaker had also to give the monastery a vineyard at Tanga, in Fundătură, which the same starets was selling, on 8 April 1657, again to Iani the chamberlain for 20 golden coins $^{39}$.

Among the parties injured - boyars, monasteries, landlords in general - there were also the merchants. For instance, some felt amounting to 700 thalers was stolen by two brothers, Dumitru and Vasilie, from an Armenian, Stețco, a merchant from Lviv, while he was in Moldavia in 1608. The perpetrators fled the country, and the ones who had to pay for them were their brother and sister, Lucoci and Nastasia. That was a typical case of family criminal responsibility, as Lucoci was sent to prison. The saving gesture was made by Nastasia, wife of Cărăiman the cupbearer, and her son, Dumitru Buhus, who paid 500 thalers to the injured merchant ${ }^{40}$. Isar the chamberlain was plundered, at Boureni, being with other merchants who were murdered, by Vasilie and his brother, Ionașco: "they took from him a real fortune, three thousand lei, cash,

${ }^{37}$ DRH, A. Moldova, XXV, p. 378-379, no. 367 (document from June 1640).

${ }^{38}$ Documente privitoare la istoria oraşului Iaşi [Documents regarding the City of Iasi], vol. I, Acte interne (1408-1660) [Internal Documents], eds. Ioan Caproşu and Petronel Zahariuc, Iaşi, Editura "Dosoftei", 1999, p. 481, no. 420.

${ }^{39}$ Pravila lui Vasile Lupu [Vasile Lupu's Code] provided death punishment by hanging for such a crime (see Carte românească de invvăţătură [Romanian Book of Teachings/Vasile Lupu's Code], critical edition, Bucharest, Editura Academiei Române, 1961, Pricina 13, Pentru furii cari țân drumurile fără arme [About the unarmed highwaymen], paragraph 109, p. 67: "Whoever steals from the church any holy object, even if he stole then for the first time in life, he will be hung"; see also paragraphs 149, 152, 154, the same chapter). But Iacob the shoemaker, the one who had committed the robbery of holy objects and money from the church redeems his guilt, with a vineyard at Tanga and "some house" given to the monastery of Trei Ierarhi as a compensation (Documente privitoare la istoria oraşului Iaşi [Documents regarding the History of the City of Iasi], I, p. 487-488, no. 428).

${ }^{40}$ DIR, A. Moldova, XVII, II, p. 167-168, no. 217 (document from 15 July 1608, Iaşi); see also ibidem, p. 229-231, no. 306; Condica lui Constantin Mavrocordat [Constantin Mavrocordat's Code], II, p. 82, no. 231. 
and deeds of property amounting to nine thousand lei, and they shot him and the other friends of him, merchants, they murdered", was shown in 1635. Death punishment is invoked for these actions, after the perpetrators were imprisoned: "after that, seizing them, they put them to prison and decided in trial for them to perish, as they were wrongdoers". But the intervention of their relatives saved their lives, their guilt being redeemed ${ }^{41}$.

We have an example of theft of objects in custody (crime against property by violation of trust), whose victim another merchant, Panaioti, was about to become, in a trial document from 1659. He was on the verge of suffering a damage of money and expensive goods, namely: "five hundred golden coins and nine golden rings and a necklace of pearls, and another strand of pearls. He had given them to pries Dima from Vrancea, to keep them "during the Greek plunder, to hide them", but the church man did not admit he had them in custody. Yet, the witnesses the merchant brought to the princely court confirmed his sayings ${ }^{42}$. The merchant Iamandi made a complaint for the 41 lei that had been stolen by one of his employees, who was supposed to sell mead and wine: "and then, after selling the drinks, he took the money and fled"43.

\section{THE “PROFESSIONAL” THIEF OR ROBBER}

According to the criminal's attitude and modus operandi, one can distinguish between two categories of thieves: the common, daily, occasional one, whose behaviour was described above, and the one likely to provoke fear as a result of the violent attitude that accompanied the act. This latter type, the highway robber, considering his attacking ways, is a product of war above all ${ }^{44}$. His identity is hard to seize; but, as we are going to see, there were also boyars who went that way, most of the times as a reaction to the biased political methods in running the country and against the excessive taxation imposed by a prince who was obedient to the Porte. Unlike in the case of occasional thieves, whose heads did not fall under the executioner's sword, many times thank to their relatives' support, who were redeeming their guilt, most of the robbers seem to have broken the geographical and family ties. The space of their actions were the highways or the woods.

${ }^{41}$ DRH, A. Moldova, XXIII, p. 180-181, no. 143 (document from 25 June 1635); ibidem, p. 279282, no. 235 (document from 15 September 1635, Iaşi).

42 A. Sava, Documente putnene [Documents of Putna], I, Focşani, 1929, p. 20, no. 28 (document from 4 June 1659).

${ }^{43}$ Documente privitoare la istoria oraşului Iaşi [Documents regarding the History of the City of Iasi], II, p. 431, no. 475 (document from 12 June 1677).

${ }^{44}$ War was one of the sources for failures of individual destinies, for group violence, for preferences for weapons and intimidation. We are talking about the former combatants who returned to their homes; all they knew was how to use an arm and found it difficult to reintegrate in a society and an economy that could not offer them much (Valérie Toureille, Vol et brigandage au Moyen Âge, Paris, 2006, p. 5). 
The woods of Scânteia ${ }^{45}$, part of Codrii Iașilor on the way from Iași to Vaslui, caused fear to those who could not avoid this route, because these very criminals. This forest also gave the shivers to the Polish envoys even before getting there, as they knew it was haunted by such wrongdoers ${ }^{46}$. Some of them go through frightening experiences, as one can read in a note by the monk Niccolò Barsi regarding his travelling through Moldavia in the summer of 1633:

As we were enough companions gathered, we left Iași and, after about ten miles, as night was coming, we stopped near a lake. The next morning, after we prepared all the weapons we had, such as pistols and arquebuses - because we were going to cross that day a dense forest -, we got going placing the wagons in front of us and the weaker people in the middle, while we the others were walking by the wagons, shooting the arquebuses all the time to threaten the robbers and to make them think we were more than we really were. When we got half the way, we met four men who were running out of breath, saying they had been the highwaymen's victims, who had stolen all their wagons; but we continued our way with them heartening them and firing the aequebuses ceaselessly. When the robbers heard so many fires and saw smoke, they got scared, and leaving the wagons ran away ${ }^{47}$.

Seeing fifteen impaled people on the banks of the Prut only intensified the fear of the Italian monk ${ }^{48}$. Arriving to Iași, in 1644, the Franciscan monk Gasparo di Notto had the same memories about the way to the capital of Moldavia: "We are here, although I have tasted all misfortunes one could possibly think of..., as many times I was attacked by highwaymen"49.

Leaving the foreign travellers behind us and moving forward in time, at the end of 1689 we can find mention of a "weak" country, "overwhelmed by all flaws" in a chancellery document:

[...] from the north, the robbers go across the whole country, attacking even the holy monasteries in the mountains, which were made with great expenses and efforts by our late Princes of this land, and which were emptied by evil deeds. And because there was a big famine in the country and we took from our Turkish and Tartar rulers their customs. And together with the boyars and all country inhabitants we struggle and endeavour to be able to save money and have this poor country fight. And paying also with much money people for the defence and as the whole country was frightened at that time: in the north by the robbers from Soroca and in the direction of Orhei by the Cossacks, the South by the Tartars, and furthermore, as there was little land left, we were overwhelmed by the needs and we are unable to succeed in fulfilling everything above, because we need so much money ${ }^{50}$.

${ }^{45}$ On the territory of the village of Scânteia, on the river of Rebricea, county of Vaslui $<$ dep. Iași $>$ (DIR, A. Moldova, $14^{\text {th }}-17^{\text {th }}$ Centuries (1384-1625), Indicele numelor de locuri [Index of place names], made by Alexandru I. Gonţa, ed. I. Caproşu, Bucharest, Editura Academiei Române, 1990, p. 226).

${ }^{46}$ Călători străini despre Țările Române [Foreign Traveller about the Romanian Principalities], V, editors' note no. 51, p. 82 .

${ }^{47}$ Ibidem, p. 82.

48 "Walking around five miles, I came across the river of Prut again and, crossing it in a skiff, I saw on the other bank about 15 impaled men" (ibidem, p. 83).

49 Ibidem, p. 291

${ }^{50}$ National Archives of Iaşi, Manuscript no. 628 (Asachi Code), f. 82 (document from 31 December 1689). 
Both the danger the highwaymen represented, and the consequences of their actions in 17th century-early 19th century Moldavia can be identified in the monastery documents ${ }^{51}$. The impossibility to defend oneself from their attacks was often one of the monks' problems, which resulted in bringing into the religious establishments people who were exempted from taxes and whose duty, besides being the labour force necessary in the monastic life, was to defend those who lived there. The monks' demands to the Court for protection against the robbers' menace are numerous; we are here mentioning just a few: on 27 November 1662, Istratie Dabija gives the Monastery of Hlincea a deed of property on the land around, villages, vineyards, servants and gypsies, as well as on some stores and places for stores in Iași; the servants "because this holy monastery is near to the beech forest and without men to defend them the monks cannot live there because of the bad robbers"52; Dumitrașco Cantacuzino Voivode exempts from taxes 15 servants of the Monastery of Hlincea, who are placed there for the security of the establishment against the highwaymen, and of a pub belonging to the monastery: "as the holy monastery is close to the forest and because of the robbers, the monks cannot live there without men"53. Antioh Cantemir too exempts from all taxes, except for the compulsory one, 12 servants and one beekeeper from the monastery of Socola, and partially exempts from taxes a priest and a deacon of the same monastery, as the monastery of nuns was "right near the Codri of Iași [the woods of Iași]", in order therefore "to prevent any highwaymen from plundering the holy monastery and from murdering the nuns" ${ }^{\text {" }}$. The servants, "dwelling near the holy monastery" have the mission "to protect the holly monastery from the bad men, taking care for the robbers not to plunder it" ${ }^{\text {"5 }}$. A document from 1 March 1706 shows in a synthetical form the material situation of the monasteries in the country, either the ones subordinated to holy places, or those "under the local Church", as well as the causes for that:

$[\ldots]$ in much distress and weakness and in big devastation: first of all because of the problems of the country and of these times, which are confirmed for us all, and second of all because of the absence of peace and because of the plunders and of the robbers whom one can see in this poor country,

${ }^{51}$ See also N. Iorga's comment about the thieves' attacks from Ardeal and Maramureş against the monasteries in Bucovina, as well as the attacks of the Turks involved in the Polish-Ottoman wars (in Studii şi documente privitoare la istoria românilor [Studies and Documents regarding the Romanians' History], Bucharest, 1909, XVI, p. 128, no. I).

${ }^{52}$ Documente privitoare la istoria oraşului Iaşi [Documents regarding the History of the City of Iasi], II, p. 43, no. 42.

53 Ibidem, p. 379-380, no. 414 (document from 25 March 1674). The monasteries of Trei Ierarhi and Golia had suffered "big destructions by the Polish armies" in the context of the Polish-Ottoman wars (ibidem, p. 574, no. 654; ibidem, p. 577, no. 656).

${ }^{54}$ Documente privitoare la istoria oraşului Iaşi [Documents regarding the History of the City of Iasi], vol. III, Acte interne (1691-1725) [Internal Documents], Iaşi, Editura "Dosoftei”, 2000, p. 103, no. 121 (document from 4 November 1696).

${ }^{55}$ Ibidem, p. 258, no. 289 (document from 16 June 1705, Iaşi); ibidem, p. 446, no. 512 (document from 4 March 1716). 
because of the devil's plots and for our sins; and that is why times of big danger came that made the monks leave them, let them empty and go where they had come from ${ }^{56}$.

\section{ROBBERY AS AN EFFECT OF WAR}

Wars or the interwar periods affected, in different ways, the heritage of humanity, as a result of both the plundering actions of the foreign armies and the increasing number of highwaymen who were attacking the roads and the forests. Property deeds, documents or letters, travel accounts and internal chronicles, they all abound in information regarding the destruction that the Polish-Ottoman and the Austrian-Ottoman wars caused in the country at the end of the 17th and the beginning of the 18th centuries: houses ${ }^{57}$ and stores in Iași were burned ${ }^{58}$, deeds of property were lost ${ }^{59}$, sto$l^{6 n}{ }^{60}$, burned $^{61}$ or destroyed ${ }^{62}$, animals were slaughtered or stolen ${ }^{63}$. From a lapidary invocation of the reason why the deeds of land property were lost, i.e. "because of

56 Ibidem, p. 269, no. 299; ibidem, p. 171, no. 202 (document from 1702, July 21); ibidem, p. 222, no. 263 (document from 3 May 1704); ibidem, p. 272, no. 300 (document from 1 March 1706); ibidem, p. 327, no. 364 (document from 25 May 1709); Documente privitoare la istoria oraşului Iaşi [Documents regarding the History of the City of Iasi], vol. IV, Acte interne (1691-1725) [Internal Documents], ed. Ioan Caproşu, Iaşi, Editura “Dosoftei”, 2000, p. 311, no. 420 (document from 30 November 1740).

57 One night, under Prince Ştefan Tomşa, the house of Trifan and his wife Sora was surrounded by robbers, who "put fire to their house while they were in, and much wealth and many expensive objects burned, only they managed to save themselves" (DRH, A. Moldova, XXII, p. 49-50, no. 45; see also ibidem, p. 50-51, no. 46).

58 Condica lui Constantin Mavrocordat [Constantin Mavrocordat's Code], II, p. 625-626, no. 1401: "after the Russians wanted to rise from here, from the city of Iasi, to go to their country, they put fire to their store $<$ of Stoica the captain and his brother, Gheorghe the merchant $>$ and they looted everything they found" (document from 13 March 1740).

59 Documente privitoare la istoria oraşului Iaşi [Documents regarding the History of Iasi], IV, p. 6, no. 9; document from 27 April 1726.

60 We do not know why the documents that sanctions the selling of plots of land by the monks of the monastery of Bistriţa to the treasurer Iordache Cantacuzino had been stolen by Neculia Vicoli. Furthermore, the latter was accused of the theft of other documents as well: "he should answer for the lack of other letters as well", as it is shown in a note from the $18^{\text {th }}$ century (DRH, A. Moldova, XXVIII, p. 312, no. 365).

61 "And their documents burned in their house with other precious objects, when the robbers put fire to their house" (document from February 1634, Iaşi, in DRH, A. Moldova, XXII, p. 49, no. 45; see also ibidem, p. 50-51, no. 46).

62 Condica lui Constantin Mavrocordat [Constantin Mavrocordat's Code], II, p. 586-587, no. 1356: the fortune of governor Iordache Cantacuzino from the village of Horodinca, stolen by the "Russian armies... losing... all of his documents for the estates he has" (document from 3 May 1741); "some old documents of the house, which when the Russians came were lost" (Documente privitoare la istoria oraşului Iaşi [Documents regarding the History of the City of Iasi], IV, p. 301, no. 407; document from 2 August 1740).

${ }^{63}$ Documente privitoare la istoria oraşului Iaşi [Documents regarding the History of the City of Iasi], III, p. 531-532, no. 605; document dated after the year when the testament of the former hierarch was written $<1721$ September $1-1722$ August $31>7230$. 
the armies" $" 64$, to details regarding the war moments proper: a property document that "disappeared because of the Cossacks, when the Polish chancellor came to our country" 65 (this refers to the contribution of chancellor Jan Zamoyski to the defeat, by Ieremia Movilă, of Ştefan Răzvan, in December 1595), documents lost "in the calamity that happened during Mihai Voivode, when brigand Baba Novac used to plunder" ${ }^{\prime 66}$ (referring to the consequences of Mihai Viteazul's campaign in Moldavia, in May 1600), "when the Cossacks of Korecki plundered him and took all his fortune" (in the fight of Tătăreni, on 21 November 1615, with the help of the Polish nobles Mihai Wisniowiecki and Samuel Korecki, Alexandru Movilă defeats Ştefan Tomșa and becomes Prince of Moldavia) or the burning of the deeds of villages property belonging to the monastery of Barnovschi in Iași, together with "much fortune and vestments of the holy monastery" ${ }^{167}$ when the country was burnt down by the Cossacks headed by hetman Bogdan Hmielnitski and their allies, the Tartars, in the summer of 1650, in a political context that disadvantaged Vasile Lupu's Moldavia ${ }^{68}$. Many documents were lost during the misfortune that the country went through during the ten days since Timuș Hmielnitski had entered the country, in the summer of 1653, with the Cossack soldiers, in order to support his father-in-law in getting back the throne that he had lost to Gheorghe Ştefan ${ }^{69}$.

The devastation of the country as a result of Jan Sobieski's campaign in Moldavia in order to get to the Danube is another moment with a victim, namely, Vasile Lupu's daughter, Ruxandra, the wife of the feared Timuș. The consequences of the fire that the inhabitants of Moldavia suffered in the summer and autumn of 1686, resulting in deaths, plundered villages and towns (including Iași), destroyed goods, are all mentioned together with the tragical end of the Moldavian Princess in the Fortress of Neamt. Some of these testimonies deal especially with the deeds of property of Neamt monastery, lost "when the Cossacks entered the Fortress of Neamț and killed Princess Ruxandra" ${ }^{\text {" I }}$. It is likely that, besides the expensive goods and things that the monks

64 National Archives of Iaşi, monastery of Răchitoasa, X/44 (no. 8) (document from 8 April 1603).

65 Idem, monastery of Adam, IV/2 (document from 28 April 1603).

66 ANIC, New Acquisitions, XXXIII/7 (document dated: $16<08>-16<11>$ no month mentioned, Iaşi, according to Catalogul documentelor moldoveneşti din Arhiva Istorică Centrală a Statului [Catalogue of the Moldavian Documents in the Central Historical Archives of the State], I, Bucharest, 1957, p. 318 , no. 1377).

${ }^{67}$ National Archives of Iași, monastery of Barnovschi, II/3, f. 4 v. (document from 14 April 1652); ibidem, f. 1v.-2 (document from 12 August 1651).

68 Petronel Zahariuc, Țara Moldovei în vremea lui Gheorghe Ştefan voievod (1653-1658) [Principality of Moldavia under Voivode Gheorghe Ştefan], Iaşi, Editura Universităţii “Al. I. Cuza”, 2003, p. 70-75.

${ }^{69}$ Documente privitoare la istoria oraşului Iaşi [Documents regarding the History of the City of Iași], I, p. 511-513, no. 457; document from 23 March 1657. See also the National Archives of Iaşi, Ms. no. 629 (Asachi Code), f. 338 (document from 22 March 1654); ibidem, f. 339 (document from 23 March 1654). For details about the excursion of the Cossacks in Moldavia in 1653, see Petronel Zahariuc, Tara Moldovei [The Principality of Moldavia], p. 166-169.

70 National Archives of Iași, monastery of Neamţ, LX/20 (document from 29 April 1691, Iaşi); ibidem, CXXXI/43 (no. 42); document from 29 April 1691; ibidem, LX/21 (document from 10 June 1691, Iaşi). 
had brought into the fortress to protect them there were also the deeds of property upon the monastery estates. But, in the tumult of war, the hidden place had become a coveted target. The convent monk Giovanni Battista Volponi from Fiorentino, who stayed in Moldavia between 1678 and 1687, offered a testimony regarding the situation of Moldavia caught between the Polish-Ottoman war, more exactly about the Tartars' passage, in June 1648, through Baia as well, the way where he lived, forcing the inhabitants to hide in the woods for five weeks, as well as about the consequences of the plundering in Moldavia by the Polish troops that had Crossed the Dniester, in the autumn of 1685 and who reached, again, Baia, and even the city of Iași:

In the year of 1684, in the month of June, the Tartars came, devastated all that region neighbouring Poland, got to Baia, my residence city, looted, took slaves, then they killed them, got to woods and chases those poor creatures hidden there, and I stayed with them in those woods for five weeks, when the robbers came, around 50 of them, went to our church and took the silver cross we had hidden, and other worship objects and other things belonging to the parishioners, and they took everything. In 1685,500 Cossack soldiers of the Polish army rose, and they devastated half of Moldavia, they took whatever they found, clothes and shoes of those men, and I was myself robbed with them ..."

The replacements of princes and the armed conflicts that were smouldering or were actually taking place led to difficult losses for the country. The wish of one of Moldavia's Princes in the first half of the 18th century was "at the borders of the country, to live peacefully with neighbours", and in case of thefts and robberies "without delay to find the reasons of the fuss"72. But the fuss was big, some of the robberies taking place in the border territories being also favoured by the war state ${ }^{73}$. But, from the beginning of the 17th century and all over this century, the border territories delimitating the Romanian principalities were privileged areas for thefts. Most of these, affecting the high boyars', the monasteries' and the merchants' fortunes, were facilitated by the armed conflicts, a thing that is confirmed for instance by the rich correspondence between the authorities in Suceava and the authorities in Bistrița and Chernivtsi ${ }^{74}$. Some of the robberies were also accompanied by the murdering of the owners of the stolen goods ${ }^{75}$.

Constantin Duca Voivode confirms, on 28 September 1702, the monastery of Neamţ's property on the estates, being known that their documents "were lost when the robbers murdered Princess Ruxanda in the fortress of Neamţ and looted it" (ibidem, CXXXII/18); see also ibidem, CXXXI/43a (no. 44); ibidem, 43b (no. 44).

${ }^{71}$ Călători străini despre Țările Române [Foreign Travellers to the Romanian Principalities], VII, ed. Maria Holban, M. M. Alexandrescu-Dersca Bulgaru and Paul Cernovodeanu, Bucharest, 1980, p. 388 .

${ }^{72}$ Condica lui Constantin Mavrocordat [Constantin Mavrocordat's Code], II, p. 525-526, no. 1310 (document dated 2 December $<1741>$ ).

${ }^{73}$ Ibidem, p. 525-526, no. 1310: "at the Russians' time", Panaite the serdar [military leader] and the Turk Mehmet were robbed of bread and beehives by the men whom Sandu, former vornic [high official], had vouched for; they had fled meanwhile.

${ }^{74}$ Eudoxiu de Hurmuzaki, Documente privitoare la istoria românilor [Documents regarding the History of Romanians], vol. XV, part II (1601-1825), Bucharest, 1913, p. 779-780, no. MDCIV (docu- 


\section{PUNISHMENT: FROM PARDON TO REPRESSION}

Judicial practice shows that theft and robbery, crimes against property, were to be punished in the Middle Age with serious penalties. The hidden and unjust appropriation of some else's property, in the case of theft, and the violence accompanying this "deed", i.e. robbery, sent the perpetrators to death by hanging. The agreement reached by the culprit and victim or the victim's relatives, by means of which the culprit escaped capital punishment paying money or goods, with the consent of the Princely Court, i.e. what we know as the blood money, made possible that the authors of many of the thefts could redeem their fault by paying the victim and by paying a fine to the State. The compensation for the victim meant ceding parts of estates or even whole villages to the injured party or to a third party, usually by a person with a good material situation and an important social status, who paid off the money penalties for the accused, if the latter did not possess goods, so that he could stay alive (guaranteeing). Most of the documents that were preserved and in which theft and even robbery crimes are mentioned, testify the redeeming of guilt, by means of which the guilty party escapes capital punishment ${ }^{76}$. These documents show that the two parties reached an agreement, avoiding thus for a trial to begin; the conditions of the agreement, that is to say the "price" for the redeeming, were written down. A high official, whose legal competence had been delegated by the Prince, authenticated the arrangement deed, in which the injured and the guilty parties stand in front of the Prince who, by his "mercy", granted for the latter the guilt redeeming. Consequently, most of the thieves reached an agreement with their victims and avoided thus the judicial penalties. In many cases, the customary fine sanctioned rather the multitude of thefts that dealt with the village goods and which were accompanied by the murdering of the injured party. The

ment dates: <cca 1601>); ibidem, p. 787, no. MDCXX; ibidem, p. 787-788, no. MDCXXI (dated: <cca 1601>); ibidem, p. 784-785, no. MDCXIII (<cca 1601> August 4); ibidem, p. 852, no. MDCCIII (document from 3 May 1612, Iași); ibidem, p. 854-855, no. MDCCVI (1 June 1612, Sibiu); ibidem, p. 855, no. MDCCVII (30 August 1612, Iaşi); ibidem, p. 856-857, no. MDCCX (6 November 1612, Câmpulung); ibidem, p. 859-860, no. MDCCXVIII (11 November 1613); ibidem, p. 862, no. MDCCXXII (17 June 1615, Cluj); ibidem, p. 878-879, no. MDCCXLV (15 May 1619, Alba-Iulia); N. Iorga, Scrisori de negustori [Letters of Merchants], Bucharest, 1925, p. 71-72, no. XL (document dates: <1638-1643>); idem, Documente româneşti din arhivele Bistriţei [Romanian Documents from Bistrita Archives], I, Bucharest, 1899, p. 100-101, no. CXXXV (document dated: <cca 1650>); idem, Studii şi documente [Studies and Documents], XVI, p. 128 (document from the second half of the $17^{\text {th }}$ century).

${ }^{75}$ N. Iorga, Documente româneşti din arhivele Bistriţei [Romanian Documents from Bistrita Archives], I, p. 21, no. XXVI; Hurmuzaki, Documente [Documents], XV, 2, p. 780, no. MDCV (document dated: <cca 1601, February 11>); N. Iorga, Documente româneşti din arhivele Bistriţei [Romanian Documents from Bistrita Archives], I, p. 30-31, no. XXXIX (document from 1612).

${ }^{76}$ As regards the redeeming of the guilt, by compensating the victims and paying the fines to the Court, as well as the economic outcomes of this practice, see Cătălina Chelcu, "Şi m-am plătit dentr-această nevoie". Consecinţe economice ale răscumpărării pedepsei în Moldova (secolele XVI-XVII) [“And I paid to get me out for this". Economic Outcomes of Punishment Redeeming in Moldavia (16 ${ }^{\text {th }}-17^{\text {th }}$ Centuries)], in AIIX, L, 2013, p. 77-97. 
information provided by the Moldavian chronicles at that period are very significant, as well as the information left by different travellers, direct witnesses (things that were seen) or indirect witnesses (things that were heard from others) to thefts and robberies committed in places they happened to go through and which the Princes of the country could hardly find effectives ways to control. Among the travelling notes, we mention here the replacement of death punishment with condemnation to forced labour ${ }^{77}$, just like bastinado was one of the punishment methods against "occasional" theft ${ }^{78}$.

The temptation of a fast and easy gain, under favourable circumstances - as everything happened on the road that led Miron Barnovschi to Poland in 1629, after having been dethroned and chased away with his family ("when Prince Barnovschi left [...] through Hârlău"79) - made Isac Stârcea and Mihalcea Durac commit a robbery against the wagons with goods belonging to Gavrilaș Mateiaș high vornic [high boyar], and Prince Miron Barnovschi's brother in law (by his marriage with the Prince's sister, Sârbca ${ }^{80}$ ). The "prey" was quite significant for the two men: "money cash, one thousand three hundred and sixty gold coins, and a damask coat, and a satin furred coat, and a marten fur, and a fox fur, and an expensive brocade kaftan, and a damask kaftan, with marten furs, with pearl buttons, and a ribbed sword, and a cartridge box with silver, of at least 20 thalers, and a new carpet, and a new cover and a new carriage with the harness"; the "price" for life was proportional: brought in front of the court of Moise Movilă, Alexandru Iliaș and then of Prince Vasile Lupu, and after Mihalcea Durac had "paid for his blood" with "full" money ${ }^{81}$, Isac Stârcea, "sent... to prison and to forced labour and not recognizing his guilt" 82 , has to pay four hundred golden coins "from his goods" 83 , i.e., according to the 1636 judgment, with three parts of villages that the perpetrators had bought, together with land plots for mills and ponds ${ }^{84}$.

77 "When somebody commits some misdeed for which they do not deserve death punishment, they are sent for three years or $<$ and $>$ for life in this little town $<$ Târgu Ocna - our n. $>$, to work there in the saline" (Niccolò Barsi, în Călători străini despre Țările Române [Foreign Travellers in the Romanian Principalities], V, p. 81).

78 "When somebody is blamed of theft or other misdeed, the Prince asks the plaintiff whether they have witnesses and if they say they do, they bring them in front of the Prince immediately and the defendant is seized, his shoes are taken off in front of the Prince, and a hundred or more stick strokes are delivered, as the Prince orders", Niccolò Barsi was writing in the summer of 1633, during his first travel through Moldavia (ibidem, p. 79).

${ }^{79}$ DRH, A. Moldova, XXIII, p. 340-341, no. 304; ibidem, p. 342-343, no. 305 (15 January 1636, Iaşi).

${ }^{80}$ Aurel Golimas, Un domnitor. O epocă. Vremea lui Miron Barnovschi Moghilă, Voievod al Moldovei [A Prince. An Epoch. The Time of Miron Barnovschi Moghilă of Moldavia], Bucharest, Editura Sport-Turism, 1980, p. 28.

${ }^{81}$ DRH, A. Moldova, XXIII, p. 343, no. 305.

82 DRH, A. Moldova, XX (1629-1631), eds. I. Caproşu and C. Burac, Bucharest, Editura Academiei Române, 2011, p. 262, no. 254 (document from April 1630).

83 Ibidem.

${ }^{84}$ DRH, A. Moldova, XXIII, p. 342-343, no. 305. 
In this case, one could not say that the daily living needs were the reasons for which the two attacked, undoubtedly in a voluntary way, the convoy of fortune. Isac Stârcea's guilt, which he had previously denied, was finally proven, "after the law got him" 85 , that is after the trial took place.

But even in the case of a robber, an agreement with the victim was possible. For instance, we find out, as a result of the rectification of a judicial error concerning an assumed thief who had died in prison, suspected of having stolen, under Prince Vasile Lupu, some Turkish mares, about the sentencing to hanging of Căzacul the robber, of Prodan, and of their host, Oni from Pogoniceni, who eventually proved to be the real perpetrators ${ }^{86}$. But the same Prince showed clemency to the robber Ionașcu, son of Buchilă, who "killed a given Tiron Cucoranu and robbed him", an estate who belonged to the perpetrator being given as blood redeeming to the son of the one who had been murdered $^{87}$; or when he solved a theft complaint on 10 April 1646: "a plundering that was made by Pătrașco with other companions of him, with Huc from Hudești and with Crețul from Voicăuți, killing one hundred beehives of vornic [high boyar] Ionașco", by a similar decision (Pătrașco redeems his deed by giving an estate he owned in the village of Drăgușeni, county of Dorohoi, to the injured party, vornic Ionașco) ${ }^{88}$.

Lucky enough was also, in 1681, Pricopie, who had offered shelter to a robber, Corne, an action which caused him "trouble", as the punishment expecting him was the same as the one for the robber, that is death. But the Prince's redeeming decision saved him, as he paid the customary fine, 20 lei, and guaranteeing with an estate he owned ${ }^{89}$. A certain Vlasie, who "made himself a robber" and robbed the Gypsy Butucea, is freed of the hanging punishment by his mother, who redeems his guilt by giving an estate as a compensation to Costache, high medelnicer [steward charged with pouring the water at table] (who was probably the Gypsy's master) ${ }^{90}$. The theft of two oxen by another Pricopi the robber from the Prince's housekeeper and which he hid at Aftodor and his brother, Lupașco. These two are called at the Princely court

85 Ibidem.

${ }^{86}$ DRH, A. Moldova, XXII, p. 104-105, no. 91 (document dated: <1634 April - 1653 July>).

${ }^{87}$ DRH, A. Moldova, XXIII, p. 8, no. 6 (document from 9 January 1635).

${ }^{88}$ DRH, A. Moldova, XXVIII, p. 282-283, no. 336; ibidem, p. 403-404, no. 472 (document from 21 August 1646).

${ }^{89}$ N. Iorga, Anciens documents de droit roumain, II, Paris/Bucarest, 1931, p. 1, no. VII. In Carte românească de învăţătură [Romanian Books of Teachings/ Vasile Lupu's Code, death penalty was to be applied to both the robber and his host, in chapter 76, The punishment for those who receive in their houses thieves and robbers, paragraph 1: "The ones who will receive in their houses a thief or a robber with goods they had stolen, will be punished as the thief himself; and if they will only receive the man, alone, then they will be punished as the court decides" (p. 189); ibidem, paragraph 2: "Those who will receive in their houses highwaymen, as the highway man to be punished, with death" (p. 189).

90 National Archives of Iași, Eforia Şcoalelor din Moldova ['General Office of Schools of Moldavia], I/18 (document from 25 October 1691, Miculeşti). 
(this is probably about the sheltering of the wrongdoer and of his stolen goods $)^{91}$. The preoccupation to find the both horse thieves in Iași, and the people who had sheltered them is also shown by Constantin Nicolae Mavrocordat, according to a commandment given on 29 October $<1741>$. Addressed to the "inhabitants of all slums here, in Iași", the order ends with the following warning: "if the robbers are not found, do know that those damages will be paid from your own goods"92.

But the thefts of aliments and animals, indispensable for both food and labour, however banal they might seem for us today, were then punished, both by the codes and by the customary law, with death penalties ${ }^{93}$. But few are the documents where we can see that the thief had really been executed ${ }^{94}$. A justification for that would be the way that "exception from the rule" worked, underlined by G. Dagron, originating in the Greek term of oikovopía (transliterated oikonomia). In medieval Greek, according to the author, this signified a deviation from the norm towards a particular situation and of an ideal towards a possible, by the adaptation of the normative texts to social reality, in order to reduce the gap between the ideological models of the written law and the evolution of mores, the infinite complexity of the social fact or the subjectivity of the judge, as opposed to the objectivity of the lawgiver ${ }^{95}$. Briefly, this is about

$[\ldots]$ the balance for the gap between a legal, generally universal, but too rigid normativity, and a social normativity, which takes into consideration the particular cases and which loses rigour to gain understanding and introduces in Law the moral notion of tolerance [...], a certain type of tolerance in which the norm remains a norm, with all the exceptions it is submitted to, where unity is not compromised by the acknowledgement of differences ${ }^{96}$.

That is, a jurisprudence founded not only on the thoroughness of canons, but one to take into consideration circumstances as well, or the fragility of human nature ${ }^{97}$.

Preoccupied by the safety of access ways on the territory of Moldavia, the foreign travellers paid attention to the authority of the Moldavian authorities towards the

${ }^{91}$ Documente privitoare la istoria oraşului Iaşi [Documents regarding the History of the City of Iasi], V, p. 76, no. 138 (document dated: $<1741$ December 18>).

${ }_{92}$ Ibidem, p. 53, no. 92 (document dated: 29 October $<1741>$ ).

${ }^{93}$ Istoria dreptului românesc [History of Romanian Law], I, eds. Vladimir Hanga and Liviu P. Marcu, Bucharest, Editura Academiei, 1980, p. 439-440. See also Cătălina Chelcu, "Şi m-am plătit dentr-această nevoie", art. cit.

${ }^{94}$ Istoria dreptului românesc, I, p. 440.

95 Gilbert Dagron, "La règle et l'exception. Analyse de la notion d'économie", in Religiöse Devianz. Untersuchungen zu sozialen, rechtlichen und theologischen Reaktionen auf religiöse Abweichung im westlichen und östlichen Mittelalter, ed. D. Simon, Francfort-sur-le-Main, 1990, p. 1.

${ }^{96}$ Ibidem, p. 2.

97 Violeta Barbu, "Lex animata et le remploi des corps", in L'empereur hagiographe. Culte des saints et monarchie byzantine et post-byzantine, Actes des colloques internationaux "L'empereur hagiographe" (13-14 March 2000) and «Reliques et miracles» (1-2 November 2000) at New Europe College, textes réunis et présentés par Petre Guran avec la collaboration de Bernard Flusin, Série des publications RELINK du New Europe College, Bucharest, 2001, p. 232-233. 
criminal phenomenon of robbery. Thus, in their notes, as a result of what they saw or of what they heard, we can also find the problem of controlling road security, by taking measures of punishment against the highwaymen. Petru Bogdan Bakšić, a catholic bishop of Sofia, made a remark after a two-month stay in Moldavia, in the 1641, regarding the punitive side of Prince Vasile Lupu's rule. The drastic punishing of the robbers led, according to the prelate, to an increase of the security of the roads, a success of the princely policy, though the Moldavian border was always exposed to dangers:

Moldavians, especially those who live on the borders, are quite inclined to theft and robbery, but under this Prince $<$ Vasile Lupu - edit. $n$. $>$ it is much safer to travel, as he chased the wrongdoers from almost all over the country and he does not stop from completely extirpating them ${ }^{98}$.

Another confirmation of this state of affairs comes also from Marco Bandini, as one can see in his account about Moldavia, written between 1647 and 1648:

So, if I do not consider the bordering areas towards Transylvania and towards the Tartars, the traveller can go back and forth, travel in the highest security while having with him gold and gemstones, and one can even sleep on the $\operatorname{road}^{99}$.

Yet, the roads continue to be dangerous in the mid-17th century ${ }^{100}$. Consequently, the princely court tries to apply other ways of annihilating violence, attracting the perpetrators on its side in order to use them in punishing others. Thus, Constantin Cantemir tried, as Ion Neculce tells, to reduce the intensity of social danger of robbery during his rule:

At that time there were 40 or more highwaymen who were attacking the roads in Tara de Gios. They got eventually in front of Prince Cantemir and he forgave them. And they all came to Iași and were taken to the monastery of Galata, where they swore to serve Prince Cantemir and the country in justice. And they were given wages of 4 lei a month. And among them, Zaharie and Sandul were appointed heads, and they received written permit, to seize as many as possible. And as soon as they got to Piiatră, they found a band of foreign thieves made of Poles and Cossacks, about 200 and even more. And they attacked them by surprise, in the mist, so that they could break in and spread them and catch them alive, and they brought them to Prince Cantemir where they were impaled and hung. So after that victory, Prince Cantemir started to make squadrons of mercenaries in Roman and in Cozmeștii and in Târgul Frumos, in Hârlău, in Podul Liloia, in Iaşi. And these ones started to defeat the robbers and to catch them and bring them to Prince Cantemir, who was killing them in all kind of pains ${ }^{101}$.

${ }^{98}$ Călători străini despre Țările Române [Foreign Travellers about the Romanian Principalities], V, p. 225.

99 Ibidem, p. 342.

100 Between 1649 and 1651 , the insecurity of the roads is also noticed by the hierodeacon Iona Travelski, in Călătoria prin Moldova şi Dobrogea [Travelling through Moldavia and Dobruja] (ibidem, p. 415).

${ }^{101}$ Neculce, Opere [Works], p. 315. 
At the same time, mercenary soldiers were employed, with the same mission, by Miron Costin in the south of the country:

The same for Miron the Logothete, who being a ruler at Putna, brought together seymen and hânsari [soldiers paid from the prey they obtained - our n.] and started from there to get rid of the highwaymen. Once only, in one fight, they got 40 highwaymen and cut them in four pieces to show them impaled along the roads ${ }^{102}$.

But the means to eradicate robbery did not lead to the expected results, because "the more highwaymen they killed, the more highwaymen there were in the days of that prince"103 (Constantin Cantemir - our n.). The Turks of Bender, Soroca, Orhei and Brăila were also an object of the Moldavian authorities' attention, being suspected of or proven to have committed crimes in the villages. In the notes sent by the Prince of Moldavia to the Pashas under whose jurisdiction the "evil" Turks, "wrongdoers" and "robbers" were, he urged them to apply severe sanctions that could go up to death punishment ${ }^{104}$. That is why, the Prince asked his servants to make up a clear record with the Turks living in the villages and with their occupations ${ }^{105}$.

Catching the robbers was not only the duty of the Prince's subalterns, but also that of the country's inhabitants, who were given deadlines to fulfil the order. Thus, in the first year of Constantin Mavrocordat's rule in Moldavia, following the many complaints of the victims, in the town of Iași, of horse thefts, he asks the inhabitants of all neighbourhoods to find in two weeks the robbers who had committed the deeds: "[...] we give you all this ordinance, to take care and know what kind of people you find in your neighbourhoods, whether they are from these places, those robbers, or they come from the country, you must know what kind of people are hosted and by whom". At the end of the document, there was also a threat that they would pay themselves for the damages, in case they did not met, in the requested terms, the Prince's commandment ${ }^{106}$.

But, sometimes, the very ones who were supposed to take care of the inhabitants' security contributed in the failure of the theft annihilation process, by ignoring the judicial attributions they were invested with. Such a situation results from a series of ordinances given by Constantin Mavrocordat to several high officials, both in the border areas, and inside the territory, for not having observed the trial procedures in the cas-

102 Ibidem, p. 315-316.

103 Ibidem, p. 316.

104 Condica lui Constantin Mavrocordat [Constantin Mavrocordat's Code], III, p. 44, no. 1694 (document from 3 December $<1742>$ ).

105 Ibidem, p. 140 , no. 1951; p. 140, no. 1952; p. 58, no. 1730 ; p. 60 , no. 1736 ; p. 36, no. 1681 ; p. 43 , no. 1692; p. 128-129, no. 1913; p. 140, no. 1952; p. 178, no. 2088; Condica lui Constantin Mavrocordat, II, p. 18, no. 19, 20; ibidem, p. 82, no. 231; ibidem, p. 113, no. 326; ibidem, p. 121-122, no. 358; ibidem, p. 122, no. 359; ibidem, p. 126-127, no. 379; ibidem, p. 141, no. 418; ibidem, p. 150, no. 444.

106 Documente privitoare la istoria oraşului Iaşi [Documents regarding the History of the City of Iaşi], V, p. 53, no. 92 (document dated: 29 October $<1741>$ ). 
es of thefts and robberies; rumours had reached the Princely court of Iași that, instead of fining and sending them to the Princely prison of Iași, those officials had released the robbers, without trial, and had appropriated the stolen goods. Consequently, the Prince's dignitaries Hrisoscol former High Stolnic [Steward], governor of Chernivtsi, Iordache former High Captain of Coțmani, Dinul former Bailiff and Antohe Caragea vornici [high boyars] of Botoșani, Iliiaș former Captain of Dorohoi, Costandinache former Captain and governor of Soroca, Costandin vornic [high boyar] of Câmpulung, the vornic of Suceava, the governors of Roman and Gheorghe former Captain of Codru receive again the order to apply the ordinance, under the threat of the Prince's anger against them:

[...] you should search, and as many robbers you catch and are arrested, you send them all here, with good guards, and all those who will still commit thefts, and keep no one there at you, but after taking the customary fine, send them immediately here to prison, writing down as well everything they did in detail. And if you do not observe my commandment, and we find out that you still kept any of these robbers there or that you released them after having them seized, know that you will know my fury 107 .

\section{CONCLUSIONS}

In the 17th century and the first half of the 18th century, theft and robbery continue to be the most frequent crimes. Famine, poverty, the devastation of the country as a consequence of the numerous wars, they all encouraged the plundering of boyars, of monasteries, of merchants crossing the territory of Moldavia in that period of time, as well as of the more or less significant goods belonging to different injured parties, which anyway represented for the latter a real fortune. The roads were especially attacked by the "professional" highwaymen, the thief becoming a central character of collective fear, some of them being known and feared for their actions. Known as robbers or "wrongdoers" are also the Polish, Turkish or Tartar soldiers, for whom plundering the country was a customary thing to do when they entered the Moldavian territory or when they left it, as well as the dismissed boyars, who were discontent with the tax policies of the Princes obeying the Porte.

We can talk about simple, common theft, about repeat offence theft, the sacrilege theft, about theft by the servant's betraying the master, about robbery accompanies by violence in war contexts, or provoked by those for whom brigandage had become a "profession".

The delinquents were in their big majority men. Women are rarely present among the perpetrators, being rather accomplices, involved in small value-thefts. Most of the thieves come from the rural world, and the circumstances in which they act are generally dissolved in the framework of daily life. We are speaking about the so-called oc-

107 Condica lui Constantin Mavrocordat, II, p. 82-83, nr. 233. 
casional, daily delinquency, as opposed to the important, violent and organised delinquency ${ }^{108}$, considering the manifestation and the denouement of actions, the groups of robbers like the highwaymen hiding in the woods representing, for instance, in the eyes of the community the incarnation of danger.

Dusk and darkness were, for both the common thieves and for the highwaymen the most appropriate moments to act, in both the urban and the rural environments.

Punishing theft meant applying pecuniary penalties to the occasional thieves or to repeat offenders, as well as to highwaymen, in some of the cases, as well as repressing it. Ended with a success or a failure, the punitive gesture had a precise political significance, representing an occasion for the princely power to manifest itself. This is going to be even more visible in the second half of the $18^{\text {th }}$ century, when the official documents trying to regulate the punishments against robbers and to harmonize local with central authorities in their criminality control policies, grow more numerous.

The second half of the 18th century is also the period when we have more details about the modes of action of the wrongdoers who attempted to attack the people's lives and fortune, as well as about the protection measures against it. For instance, defending one's life and wealth with weapons during a night attack was one of the victim's modalities of rejecting it, in a case when the attacked person managed to mobilize and respond: " $[\ldots]$ in the past years, as the robbers surrounded my house during the night, armed, they wanted to murder me and my household and, with the help from God, I defended myself with weapons and I saved my life and my household from the death that had been prepared for me" 109 . In the case of violent actions, the dénouement was always unpredictable. We must say that the internal historical sources up to the mid-18th century regarding the criminal deeds (theft, robbery, murder) are not very generous in details. Most of them are civil certificates, confirming property upon movable or immovable goods, containing stereotyped formulas, lacking details, even in cases where the transfer of a movable or immovable good was made as a result of the compensation of some theft of robbery. The documents include lapidary information about the author, the deed and the punishment. The redeeming of guilt, in case the perpetrators could afford it, as a result of village, family or conjugal solidarity ${ }^{110}$, proves that the objective of the judicial authority was to recover damage. The redeeming offered by the thief to the injured party had a double significance: the former did not lose their "blood", the latter re/built their fortune, with the money, animals, and especially the plots of land that the perpetrator had cede.

As for the explanation of the antisocial deeds of theft and robbery, this aspect is difficult to identify thoroughly, because, again, of the stereotypical and scarce information

108 See Valérie Toureille, Vol et brigandage au Moyen Âge, p. 3.

${ }^{109}$ Documente privitoare la istoria oraşului Iaşi [Documents regarding the History of the City of Iasi], vol. VIII, Acte interne (1781-1790) [Internal Documents], ed. Ioan Caproşu, Iaşi, Editura "Dosoftei”, 2006, p. 405 , no. 317.

${ }^{110}$ Lett Didier, Claude Gauvard, "De grace especial", Crime, État et Société en France à la fin du Moyen Âge, in "Médiévales", 12, no. 25, 1993, p. 151. 
we can find in the sources corresponding to the period we focused on. We can assume here, trying to clarify this issue, a problem of impulse control; the fortune that the thieves became aware of, in the frequently invoked circumstances of poverty, and considering the opportunity to criminally appropriate it, was a temptation.

\section{BIBLIOGRAPHY}

\section{Sources:}

Arhivele Naţionale Iași (National Archives of Iași), Bishopric of Huşi; Monastery of Barnovschi; Monastery of Brazi; Monastery of Doljeşti; Monastery of Neamţ; Monastery of Precista - Răducanu; Monastery of 'Sf. Ioan Gură de Aur' [St. John Chrysostom]; Ştoboreni Monastery; Eforia Şcoalelor din Moldova ['General Office of Schools of Moldavia]; Ms. no. 572 (Register of the Monastery of Răchitoasa); Ms. no. 628, Asachi Register; Ms. no. 818 (Condica Moşiei Miclăuşeni - Code of the Estate of Miclăuşeni).

Arhivele Naționale Istorice Centrale (Central National Historical Archives), New Acquisitions; Collection S. Zotta.

Călători străini despre Țările Române [Foreign Travellers to the Romanian Principalities], V, ed. Maria Holban, M. M. Alexandrescu-Dersca Bulgaru and Paul Cernovodeanu, Bucharest, 1973; VII, ed. Maria Holban, M. M. Alexandrescu-Dersca Bulgaru and Paul Cernovodeanu, Bucharest, 1980.

Catalogul documentelor moldoveneşti din Arhiva Istorică Centrală a Statului [Moldavian Documents Catalogue in the Central State Historical Archives], III, Bucharest, 1968; IV, Bucharest, 1970; V, Bucharest, 1974; Supliment (Supplement), I, Bucharest, 1975;

Condica lui Constantin Mavrocordat [Constantin Mavrocordat's Code], vol. II-III, ed. Corneliu Istrati, Iaşi, Editura Universităţii “Al. I. Cuza”, Iași, 2008.

Din tezaurul arhivistic vashian. Catalog de documente, 1393-1877 [Archives Treasury of Vaslui. Document Catalogue], Bucharest, 1986.

Documenta Romaniae Historica, A. Moldova, XX (1629-1631), eds. I. Caproşu and C. Burac, Bucharest, Editura Academiei Române, 2011; XXI (1632-1633), eds. C. Cihodaru, I. Caproşu and L. Şimanschi, Bucharest, Editura Academiei Române, 1971; XXII (1634), eds. C. Cihodaru, I. Caproşu and L. Şimanschi, Bucharest, 1974; XXIII (1635-1636), eds. Leon Şimanschi, Nistor Ciocan, Georgeta Ignat and Dumitru Agache, Bucharest, Editura Academiei Române, 1996; XXIV (1637-1638), eds. C. Cihodaru and I. Caproşu, Bucharest, Editura Academiei Române, 1998; XXV (1639-1640, eds. Nistor Ciocan, Dumitru Agache, Georgeta Ignat and Marius Chelcu, Bucharest, Editura Academiei Române, 2003; XXVI (1641-1642), ed. I. Caproşu, Bucharest, Editura Academiei Române, 2003; XXVII (1643-1644), eds. Petronel Zahariuc, Cătălina Chelcu, Marius Chelcu, Silviu Văcaru, Nistor Ciocan and Dumitru Ciurea, Bucharest, Editura Academiei Române, 2005; XXVIII (1645-1646), eds. Petronel Zahariuc, Marius Chelcu, Silviu Văcaru and Cătălina Chelcu, Bucharest, Editura Academiei Române, 2006.

Documente privind istoria României (Documents regarding the history of Romania), $14^{\text {th }}-17^{\text {th }}$ Centuries (1384-1625), Indicele numelor de locuri [Index of place names], made by Alexandru I. Gonţa, ed. I. Caproşu, Bucharest, Editura Academiei Române, 1990.

Documente privind istoria Romaniei (Documents regarding the history of Romania), $17^{\text {th }}$ Century, A. Moldova, vol. II (1606-1610), Bucharest, 1953; vol. IV (1616-1620), Bucharest, 1956.

Documente privitoare la istoria oraşului Iaşi [Documents regarding the City of Iasi], vol. I, Acte interne (1408-1660) [Internal Documents], eds. Ioan Caproşu and Petronel Zahariuc, Iaşi, Editura "Dosoftei", 1999; vol. II, Acte interne (1661-1690) [Internal Documents], ed. Ioan Caproşu, Iaşi, Editura "Dosoftei”, 2000; vol. V, Acte interne (1741-1755) [Internal Documents (1741-1755)], ed. Ioan Caproşu, Iaşi, Editura “Dosoftei”, 2001. 
Documente româneşti din arhivele Bistriţei [Romanian Documents from Bistrita Archives], I, Bucharest, 1899.

„Dr. Constantin I. Istrati” Collection (1429-1945). Inventar arhivistic [Archive Inventory], eds. Nicolae Chipurici and Tudor Răţoi, Bucharest, 1988.

Ghibănescu Gh., Surete şi izvoade (Documents and Registers), XXIV, Iaşi, 1939.

Hurmuzaki Eudoxiu de, Documente privitoare la istoria românilor [Documents regarding the History of Romanians], vol. XV, part II (1601-1825), Bucharest, 1913.

Iorga N., Documente româneşti din arhivele Bistriţei [Romanian Documents from Bistrita Archives], I, Bucharest, 1899.

Iorga N., Studii şi documente privitoare la istoria românilor [Studies and Documents regarding the Romanians' History], XVI, Bucharest, 1909.

N. Iorga, Scrisori de negustori [Letters of Merchants], Bucharest, 1925.

N. Iorga, Anciens documents de droit roumain, II, Paris/Bucarest, 1931.

Pravila lui Vasile Lupu [Vasile Lupu's Code] provided death punishment by hanging for such a crime (see Carte românească de învăţătură [Romanian Book of Teachings/Vasile Lupu's Code], critical edition, Bucharest, Editura Academiei Române, 1961.

Sava. A., Documente putnene [Documents of Putna], I, Focşani, 1929.

\section{Literature:}

Auspert Sarah, Parmentier Isabelle, Rousseaux Xavier, Buveurs, voleuses, insensés et prisonniers à Namur au XVIIIe siècle. Déviance, justice et régulation sociale au temps des Lumières, Namur, Presses Universitaires de Namur, 2012.

Banditisme et violence sociale dans les sociétés méditerranéenne: actes du colloque de Bastia, (27-29 mai 1993), textes réunis par Georges Ravis-Giordani et Ange Rovere, Ajaccio, La marge éditions, 1993.

Barbu Violeta, "Lex animata et le remploi des corps", in volume L'empereur hagiographe. Culte des saints et monarchie byzantine et post-byzantine, Actes des colloques internationaux "L'empereur hagiographe" (13-14 March 2000) and «Reliques et miracles» (1-2 November 2000) at New Europe College, textes réunis et présentés par Petre Guran avec la collaboration de Bernard Flusin, Série des publications RELINK du New Europe College, Bucharest, 2001, p. 224-248.

Cadiet Loïc, Chauvaud Frédéric, Gauvard Claude, Schmitt Pantel Pauline, Tsikounas Myriam (dir.), Figures de femmes criminelles de l'Antiquité à nos jours, Paris, Publications de la Sorbonne, 2010.

Caiete de antropologie istorică, yr IX, no. 1 (16), Cluj-Napoca, January-June 2010, an issue dedicated to: Haiducie, brigandaj şi disciplinare social ['Haiducie', Brigandage and Social Discipline].

Chelcu Cătălina, "Şi m-am plătit dentr-această nevoie". Consecinţe economice ale răscumpărării pedepsei in Moldova (secolele XVI-XVII) ["And I paid to get me out for this". Economic Outcomes of Punishment Redeeming in Moldavia $\left(16^{\text {th }}-17^{\text {th }}\right.$ Centuries $\left.)\right]$, in „Anuarul Institutului de Istorie «A. D. Xenopol»", L, 2013, p. 77-97.

Chiffoleau Jacques, Les justices du pape. Délinquance et criminalité à Avignon au XIV siècle d'après les registres de la cour temporelle, Paris, Publications de la Sorbonne, 1984.

Dagron Gilbert, "La règle et l'exception. Analyse de la notion d'économie", in Religiöse Devianz. Untersuchungen zu sozialen, rechtlichen und theologischen Reaktionen auf religiöse Abweichung im westlichen und östlichen Mittelalter, ed. D. Simon, Frankfurt/Main, 1990, p. 1-18.

Di Bella M. P. (dir.), Vols et sanctions en Méditerrannée, Amsterdam, Éditions des Archives contemporaines, 1998.

Dupont-Bouchat Marie-Sylvie, Le crime pardonné: la justice réparatrice sous l'Ancien Régime $\left(X V I^{e}\right.$ XVIII siècle), dans "Criminologie", 32, no. 1, 1999, p. 31-56.

Garnot Benoît (dir.), De la déviance à la délinquance, $X V^{e}-X X^{e}$ siècles, Dijon, Éditions universitaires de Dijon, 1999.

Garnot Benoît, Au temps de bons juges d'Ancien Régime, dans "L'Histoire”, 2010, p. 78-83. 
Garnot Benoît, La violence dans la France moderne: une violence apprivoisée?, dans Mélanges offerts au professeur Maurice Gresset. Des institutions et des hommes, Besançon, Presses universitaires de Franche-Comté, 2007, p. 93-101.

Gauvard Claude, «De grace especial». Crime, État et Société en France à la fin du Moyen Âge, 2 vol., Paris, Publications de la Sorbonne, 1991.

Gauvard Claude, Violence et ordre public au Moyen Âge, Paris, Picard, 2005.

Geary Patrick J., Le vol des reliques au Moyen Âge. Furta sacra, traduit de l'anglais par Pierre-Emmanuel Dauzat, Paris, Aubier, 1993.

Geremek Bronisław, Les marginaux parisiens aux XIV et XV siècles, Paris, Flammarion, 1976.

Golimas Aurel, Un domnitor. O epocă. Vremea lui Miron Barnovschi Moghilă, Voievod al Moldovei [A Prince. An Epoch. The Time of Miron Barnovschi Moghilă of Moldavia], Bucharest, Editura Sport-Turism, 1980.

Istoria dreptului românesc [History of Romanian Law], I, eds. Vladimir Hanga and Liviu P. Marcu, Bucharest, Editura Academiei, 1980.

Le Roy Ladurie Emmanuel, Montaillou, sat occitan de la 1294 până la 1324, vol. II, translation in Romanian, foreword and notes by Maria Carpov, Bucharest, Editura Meridiane, 1992.

Lemesle Bruno, Conflits et justice au Moyen Âge, Paris, PUF, 2008.

Mazilu Dan Horia, Lege şi fărădelege în lumea românească veche, Iași, Polirom, 2006.

Nicoară Toader, Sentimentul de insecuritate în societatea românească la începuturile timpurilor moderne (1600-1830) [The Feeling of Insecurity in Romanian Society in Early Modern Times (1600-1830)], vol. I, Cluj-Napoca, Editura Accent, 2002, and vol. II, 2005.

Nirenberg David, Violence et minorités au Moyen Âge, Paris, PUF, 2001.

Stoide C. A., Despre schitul Fătăciune şi despre satele Cernueşti şi Praja [About the Skete of Fătăciune and about the Villages of Cernueşti and Praja], in „Revista Istorică Română”, XIV, 1944, p. 200217.

Toureille Valérie, Vol et brigandage au Moyen Âge, Paris, Presses Universitaires de France, 2006.

Zahariuc Petronel, Thara Moldovei in vremea lui Gheorghe Ştefan voievod (1653-1658) [Principality of Moldavia under Voivode Gheorghe Ştefan], Iaşi, Editura Universităţii “Al. I. Cuza”, 2003. 
